\title{
Mio-Pliocene seasonality on the Snake River plain: comparison of faunal and oxygen isotopic evidence
}

\author{
Gerald R. Smith and William P. Patterson \\ Museum of Paleontology and Department of Geological Sciences, University of Michigan, Ann Arbor, MI 48109, USA
}

(Received January 20, 1993; revised and accepted March 4, 1993)

\begin{abstract}
Smith, G.R. and Patterson, W.P., 1994. Mio-Pliocene seasonality on the Snake River plain: comparison of faunal and oxygen isotopic evidence. Palaeogeogr., Palaeoclimatol., Palaeoecol., 107: 291-302.

Analysis of fish faunas and oxygen isotopic composition of a fish otolith from lacustrine deposits of southwestern Idaho provide a means of evaluating regional Miocene and Pliocene climates. A disharmonious assemblage consisting of coldwater salmon and trout and warmwater sunfish and catfish from the Chalk Hills Formation of the Snake River Plain indicates that the climate of the late Miocene was warm and moist with cool summers and mild winters. Colonization of the lake by deepwater sculpins and whitefish in the Pliocene indicates that the climate was moist and equable, but with summers cooler than either the Miocene or Quaternary. Oxygen isotopic variation among seasonal growth rings in an aragonitic otolith of a Pliocene littoral sunfish suggests a seasonal range of temperatures locally more equable than at present. Extremely depleted values of $\delta^{18} \mathrm{O}$ in carbonates suggest that the lake was maintained by tributaries from high-elevation watersheds, with locally low evaporation, rather than high precipitation.
\end{abstract}

\section{Introduction}

The ratio of stable oxygen isotopes in carbonate minerals is now widely used to estimate paleotemperatures (Faure, 1986) based on the temperaturedependent fractionation relationship of those isotopes in carbonates (Urey, 1947). Oxygen isotopic compositions in aragonite of fish otoliths are stable records of environmental conditions during the life stages of the fish (Devereaux, 1967; Degens et al., 1969; Radtke, 1984a, b; Radtke, 1987; Radtke, 1989; Kalish, 1991a, b; Patterson et al., 1993). Otoliths are accretionary structures in fish ears; each fish possesses three pairs, the largest are usually 2-10 $\mathrm{mm}$ long and almond shaped. Aragonite is accreted in daily growth bands in the first several years of the fish's life (Panella, 1971; Brothers et al., 1976). Seasonal differences in growth rate are recorded as textural and compositional differences (Gauldie, 1993) that enable recognition of events in the life history of the fish (Campana, 1989; Bagenal, 1974). Seasonal varia- tions in isotopic composition can be measured in microsamples of aragonite milled from individual growth bands. Carbonate isotopic composition can be used to determine temperature if (a) the isotopic composition of the water and (b) the temperaturefractionation relationship are known.

Previous continental paleoclimatic work has been hindered by inability to quantify isotopic compositions of ancient hydrologic systems, inapplicability of equations calibrated to other carbonates, and suspicion that biological fractionation factors might be species-specific (Radtke, 1984a). We attempt to solve these problems in two ways: (a) Paleo-compositions of oxygen isotopes in certain lake waters can be calculated if the paleotemperature is known for a key, stenothermic species, in this case, deepwater sculpins. (b) Studies of modern deepwater sculpins in lakes with known isotopic composition and hypolimnion temperatures, coupled with laboratory experiments in which fish were raised at known temperatures and isotopic compositions, have enabled refinement of 
the fractionation factor in the temperature equation and identification of minimal variance due to biotic effects, at least in many common families of freshwater fishes (Patterson et al., 1993). Fossil aragonite that has not been altered to calcite is assumed to retain the original oxygen isotopic signal, supplying a recoverable record of temperatures in different seasons of growth during ancient times.

Seasonality is an element of paleoclimate with special significance to the survival and distribution of organisms (Axelrod, 1967; Graham and Meade, 1987). The seasonal distributions of heat and moisture are therefore extremely important to paleobiological and paleoclimatic studies. However, because seasonality is usually reconstructed indirectly from taxon distributional data, results are subject to the criticism that evolution of tolerance would lead to errors in interpretation. Therefore, an independent source of information about summer and winter temperatures is necessary. Oxygen isotopic composition of otolith aragonite provides the opportunity to test seasonality hypotheses inferred from faunal and floral data.

The example explored here is based on the fish fauna (Smith et al., 1982) of lacustrine beds of Miocene and Pliocene age in southwestern Idaho (Malde and Powers, 1962). The early Pliocene fauna, especially, shows a disharmonious composite assemblage consisting of warmwater sunfish, catfish, and minnows with coldwater trout, whitefish, and sculpins. Hibbard (1960) proposed equable late Tertiary climates based on disharmonious faunas. His evidence depended on the demonstration that in North America, the southern ranges of cold-adapted animals are often limited by summer heat and the northern ranges of warmadapted animals are determined by severity of winters. Therefore the disharmonious composite of warm- and cold-limited animals suggests a climate with cooler summers but a longer growing season (milder winters) than at present. In the present study, the seasonal isotopic variations in the otolith aragonite of a sunfish are compared with the faunal interpretations and support the conclusion that Miocene as well as early and middle Pliocene climates on the Snake River Plain were more equable than subsequent climates.

\section{Methods}

Data for this study come from two sources: (1) Distribution of Miocene and Pliocene fishes compared with the distribution of their recent relatives, and (2) Oxygen isotopic composition of fish otoliths and bones. Fossils from the Miocene Chalk Hills Formation and the Pliocene Glenns Ferry Formation were collected by University of Michigan geologists and paleontologists working on the Snake River Plain in Owyhee and Elmore counties in southwestern Idaho and Malheur County, Oregon (Kimmel, 1982; Smith et al., 1982). Lacustrine facies of the Chalk Hills and Glenns Ferry formations each record the existence of a lake basin about the size of present-day Lake Ontario. The lakes that occupied this basin were interrupted by a low-stand hiatus from about 5.9 $\mathrm{Ma}$ to about 3.3 Ma, at least on the basin margin (Kimmel, 1982). The lakes were a part of an Intermountain Great Lakes system seen in a Tertiary and Quaternary sedimentary record in California, Oregon, Washington, Idaho, Utah, and Nevada, from the Cascades on the west to the Wasatch mountains on the east (King, 1878; Smith, 1978; Gustaffson, 1978; Cole and Armentrout, 1979).

\section{Paleontology}

Twenty-five species lineages of fishes from the Glenns Ferry and Chalk Hills formations represent a sample with greater species diversity of cold- and warm-dependent elements than in any western North American lake today (Smith, 1978, 1981). This diversity includes many lineages whose modern North American distributions relative to temperature are well known (Radforth, 1944; LaRivers, 1962; Scott and Crossman, 1973; Trautman, 1981; Moyle, 1976; Lee et al., 1980). The general assumption on which this study is based is that known temperature limits of modern descendants or close relatives of fossil fishes allow us to infer temperatures where the fossil forms lived. More specifically, the inferences are limited to the aspects of seasonal temperature that are known to exert the most powerful limitations on growth (Brett, 1979) and survival, especially during 
early life history (Blaxter, 1974). We will focus on the limiting factors operating at the northern borders of warmwater fish ranges and the southern borders of coldwater fish ranges in western North America.

The southern distributional limits of coldwater fishes-sculpins, trout, and whitefish-are determined by hot summer extremes. There is an upper temperature above which the metabolic rate (in cal./mass/hour) exceeds the rate at which nutrients are processed. (Certain coldwater fishes survive hot atmospheric temperatures in the cold hypolimnion of lakes, but the colonization of those lakes must have been through shallow connections, so they are subject to, and evidence for, the limits imposed by regional climate.)

The northern limits of warmwater fishes-catfish and sunfish - are determined by the length of the growing season, or conversely, limited by the length of winters. Warmwater fishes in temperate climates can tolerate temperatures close to $0^{\circ} \mathrm{C}$ for several months. These species do, however, require a growing season long enough and warm enough (measured in degree days) to reach sufficient size, with sufficient stored reserves, to survive through the winter into the next growing season. Upon maturity, female fish require a growing season sufficient to produce hundreds to thousands of eggs for spawning the following spring.

Presence of both coldwater and warmwater species together indicates equable temperaturesin this case, cool summers and long frost-free seasons. Extinction of both coldwater and warmwater species from southwestern Idaho near the end of the Pliocene indicates increased seasonality (decreased equability) as glacial climate approached.

Correlations between distributional limits and temperature isotherms have been used to identify and quantify the limiting temperature parameters (Radforth, 1944). It is now apparent that this kind of faunal evidence is applicable to ancient climates only when it can be demonstrated that the temperature requirements for a fossil species apply to the whole clade including its recent relatives. That is, if all of the known members of a natural group are restricted to certain temperature conditions, then a fossil member can be inferred, by parsi- mony, to possess the group's temperature tolerance. This can be demonstrated for sculpins and salmonids, all of which live in coldwater (Fig. 1), and for sunfish and catfish, all of which live in warmwater (Fig. 2). In the present study, measurement of oxygen isotopic composition of calcium carbonate from fossil forms is used to test the hypothesis that Pliocene sunfish and sculpins preferred temperatures similar to those preferred by their recent relatives.

To test the equability hypothesis, we sampled seasonal growth bands from an otolith of a shallow, inshore species-Archoplites taylori, the Lake

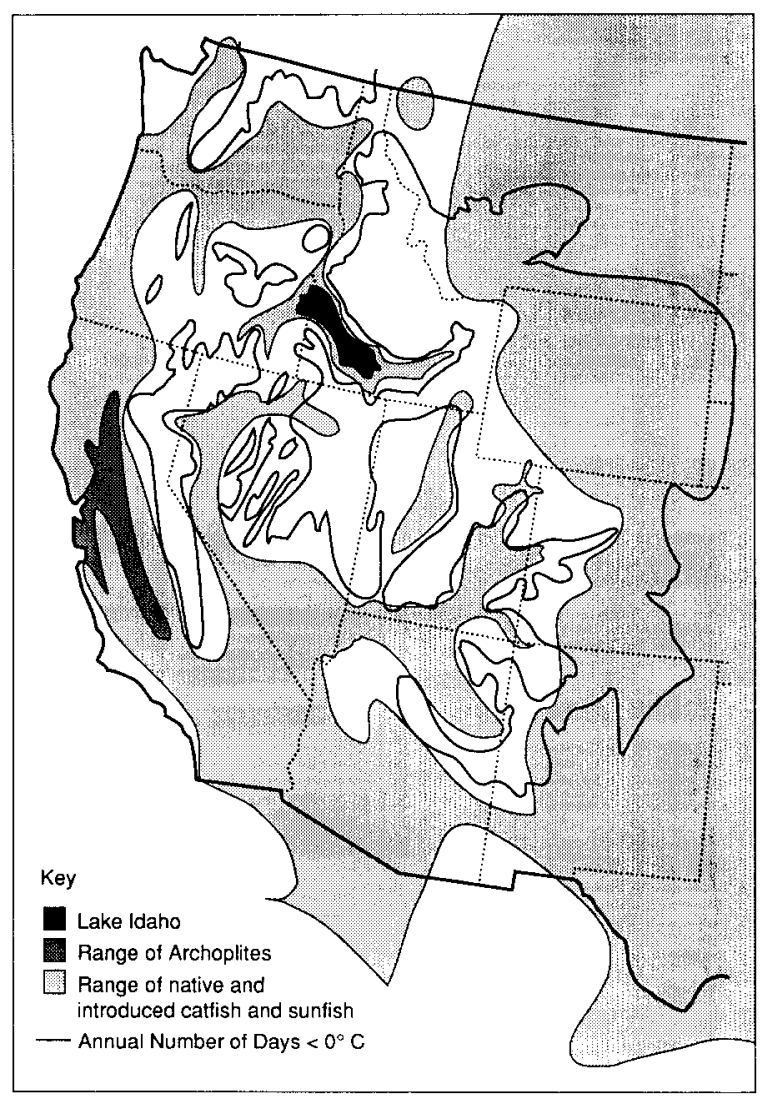

Fig. 1. Distributional limits of catfish (Ictaluridae) and sunfish (Centrarchidae) in North America, in relation to the number of frost-free days. Black represents the approximate outhine of Lake Idaho. The lightly-shaded area has either native or introduced sunfish and (or) catfish. The darkly-shaded area encloses the native range of Archoplites interruptus, which is enclosed in the region of $300+$ day growing seasons. The dark line is the isopleth for growing season 175 days long. These species are usually excluded from areas with shorter growing seasons. 


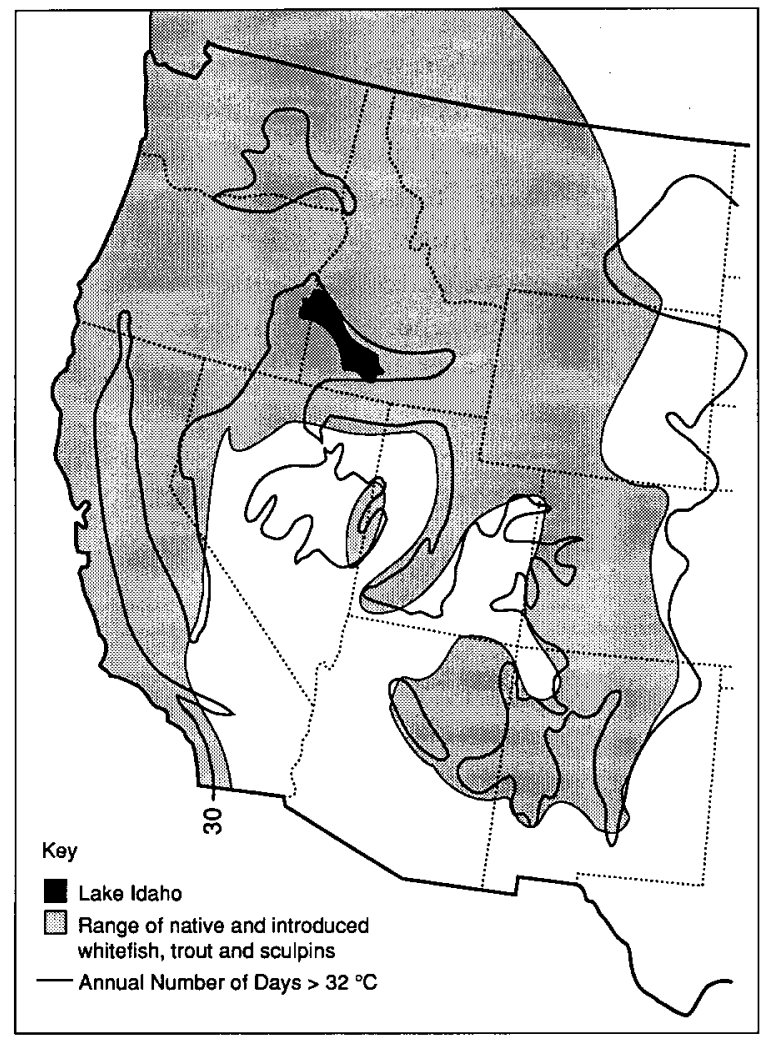

Fig. 2. Distributional limits of trout and whitefish, family Salmonidae, and sculpins, family Cottidae, in North America, relative to isopleths for summer maximum temperature. Black represents the approximate outline of Lake Idaho. The shaded area is occupied by one or more members of the three coldwater families. The dark line is the isopleth for 30 days per year with temperatures higher than $32^{\circ} \mathrm{C}$. The coldwater fishes are usually excluded from areas experiencing more than 30 hot days.

Idaho sister species of the Sacramento sunfish. The otolith was collected from the littoral facies of the Glenns Ferry Formation at the Sand Point locality, $2.8 \mathrm{~km}$ SE Hammett, Elmore Co., Idaho, at 850 $\mathrm{m}$ elevation. We drilled approximately $25 \mu \mathrm{g}$ of powder from each of 32 growth rings representing the first 3 years of the fish's life (Table 3, Fig. 3). These samples represented different intervals of time, depending on the growth rate-probably times as short as two weeks during the summer to perhaps as long as 6 months during the winter. The fish was about 12 years old, but because growth rates decline with maturity (Fig. 3), later years offered less material to sample and our sample sizes would have given us average temper-

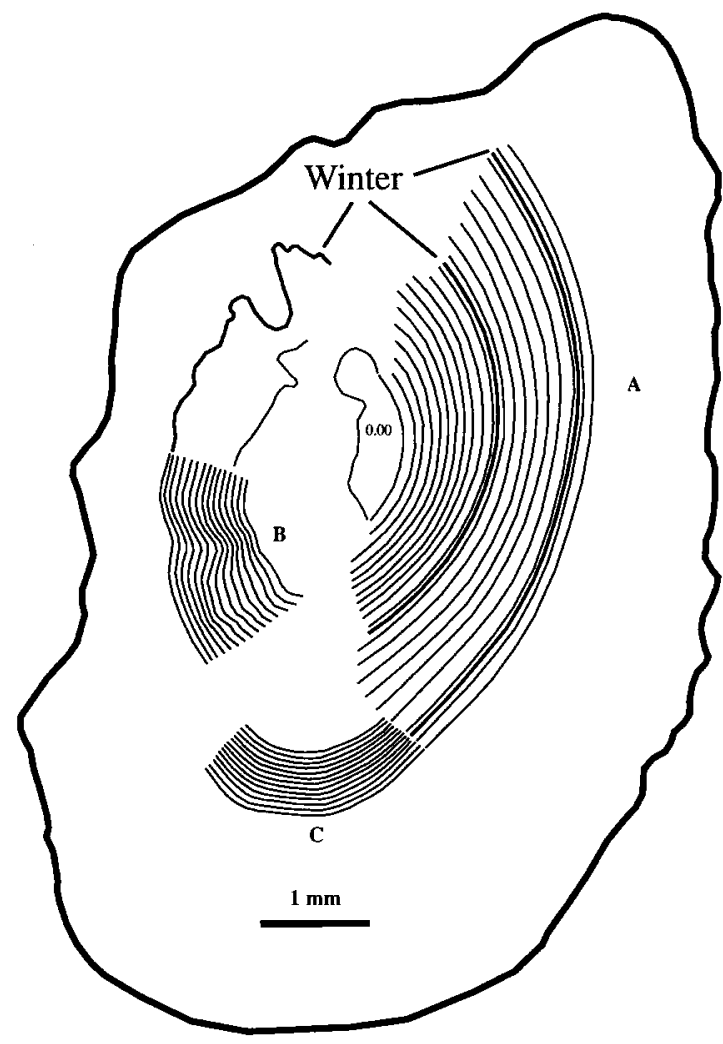

Fig. 3. Camera lucida tracing of sagitta of Archoplites taylori showing drill paths relative to growth rings. Path group A controlled by computer, milling increments of $2-10 \mu \mathrm{m}$ guided by individual keystrike instructions under microscope; group $\mathrm{B}$ and $\mathrm{C}$ controlled by program STEPPER, following digitized paths.

atures for longer periods of the fish's life, causing higher errors in measures of seasonal extremes.

The winter sample does not estimate the minimum winter temperature precisely, because if the temperature reached freezing, it was lower than the fish's metabolically active range and therefore below its growth limits. LaRivers (1962) reported that most specimens in a midwinter sample of Archoplites interruptus in Walker Lake, Nevada, were not feeding at $10^{\circ} \mathrm{C}$, so we assume that to be near the minimum active metabolic temperature. Spawning temperatures for this species are $21-29^{\circ} \mathrm{C}$ (McCarraher and Gregory, 1970), which indicates that the recordable temperature range for Archoplites otoliths is conservatively expected to be at least $19^{\circ} \mathrm{C}$. 


\section{Isotope geochemistry}

The fractionation factor, $\alpha$, is inversely proportional to the temperature at which the carbonate was precipitated. This dictates that relatively more ${ }^{18} \mathrm{O}$ is incorporated in aragonite at lower temperatures. The literature contains a diversity of temperature-fractionation relationships for calculating paleotemperatures from carbonates. Modifications of equations based on a variety of systems (e.g., Epstein et al., 1953; Horibe and Oba, 1972; Grossman and $\mathrm{Ku}, 1986$ ) are not applicable to freshwater fish (Patterson et al., 1993). In order to develop and apply an empirical equation which describes the isotopic fractionation relationship between fish otolith aragonite and water over a range of earth surface temperatures, experimental evidence was required. Data on oxygen isotopic compositions of otoliths grown at known temperatures were coupled with the measured isotopic compositions of the waters in which they grew, to empirically determine $\alpha$ for otolith aragonite. By combining data from laboratory experiments with data from several lakes, Patterson et al. (1993) showed that the linear relation of $\alpha$ to temperature can be represented by the least squares fit of $10^{3}$ $\ln \alpha$ relative to $\mathrm{T}^{-1} \mathrm{~K}$, or,

$$
\begin{aligned}
10^{3} \ln \alpha= & 18.56( \pm 0.319)\left(10^{3}\right) \mathrm{T}^{-1} \mathrm{~K} \\
& -33.49( \pm 0.307)
\end{aligned}
$$

Using the above equation, the oxygen isotopic composition of ancient large-lake systems can be calculated from carbonate precipitated at equilibrium, if the temperature of precipitation is known. The hypolimnion of deep temperate lakes is stable at $3.5-4.0^{\circ} \mathrm{C}$, the temperature at which fresh water is most dense (Hutchinson, 1957). All deep northern lakes are inhabited by obligate, benthic, coldwater organisms, such as deepwater sculpins (fishes of the genus Myoxocephalus). The temperature at which carbonate was precipitated by those organisms is assumed to have been near $4^{\circ} \mathrm{C}$, based on their occurrence in the hypolimnion of the Laurentian Great Lakes (Scott and Crossman, 1972; Patterson et al., 1993). Lake Idaho has an exceptionally rich sculpin fauna of seven species, including two species of deepwater sculpins in the
Holarctic genus Myoxocephalus. Spines of deepwater sculpins, Myoxocephalus idahoensis, in Lake Idaho show carbonate isotopic values of $\delta^{18} \mathrm{O}=$ $-11.1 \%$ PDB (values for spine carbonate are adjusted by $-1 \%$ to a value of $\delta^{18} \mathrm{O}=-12.1 \%$, based on the isotopic differential between aragonite and spine carbonate discovered by experiments on recent sculpins). Ten additional samples of three other species of sculpins in the genus Kerocottus, known from deep to moderate depths, range from $\delta^{18} \mathrm{O}=-11.4$ to $-15.6 \%$. Their inferred depth gradient corresponds well with that predicted from sedimentary evidence (Smith, 1987). Knowing that deepwater sculpins precipitate carbonate with $\delta^{18} \mathrm{O}$ of $-12.1 \%$ PDB at a temperature of $4^{\circ} \mathrm{C}$ we calculate the isotopic composition of the lake to be $\delta^{18} \mathrm{O}=-15.5 \%$ SMOW. Because the lake is large and dimictic, we assume thorough mixing of the water column, with respect to isotopic composition. If this assumption is correct, the estimated value for the water enables calculation of the seasonal temperature estimates from aragonite accreted in the otolith growth bands of the sunfish.

Isotopic analysis of individual growth rings is conducted on microsamples of $10-30 \mu \mathrm{g}$ of aragonite, milled from the growth lines of a sectioned and polished sagitta otolith using a drill bit over a motorized, computer-controlled micropositioning stage (Patterson et al., 1993). The sample powders were roasted at $200^{\circ} \mathrm{C}$ in vacuo to remove volatile organic material and reacted at $73^{\circ} \mathrm{C}$ with anhydrous phosphoric acid in a Finnigan "Kiel" carbonate preparation system coupled to a Finnigan MAT 251 ratio mass spectrometer. Isotopic data were corrected for acid fractionation and contribution of ${ }^{17} \mathrm{O}$ and reported in per mil $(\%)$ relative to the PDB standard. Calibration was monitored and standardized to within $0.1 \%$ by daily analysis of NBS- 18 and NBS-19 powdered carbonate.

\section{Results}

Seasonality inferred from faunal distributions

Limitation by length of the growing season

Warmwater fishes are abundant in the Miocene and Pliocene faunas of southwest Idaho (Fig. 1, 
TABLE 1

Warmwater fishes that inhabited the Snake River floodplain and lakes during the Miocene and Pliocene, but which do not live there now (except related catfish, by introduction)

\begin{tabular}{|c|c|c|}
\hline & $\begin{array}{l}\text { Present day } \\
\text { distribution }\end{array}$ & $\begin{array}{l}\text { Regional } \\
\text { growing season }\end{array}$ \\
\hline Archoplites (Sacramento sunfish) & Sacramento $\mathbf{R}$. & $250+$ days \\
\hline Ameiurus (bullhead catfish) & $\begin{array}{l}\text { Sacramento R.* } \\
\text { Eastern North America }\end{array}$ & $120+$ days \\
\hline Mylopharodon (hardhead minnow) & Sacramento $\mathbf{R}$. & $150+$ days \\
\hline
\end{tabular}

*Introduced.

Table 1). The three species of greatest interest-a catfish (Ameiurus vespertinus), a sunfish (Archoplites taylori), and a minnow (Mylopharodon hagermanenisis) - became extinct on the Snake River Plain at about 1.7-2 Ma. The sunfish became extinct first, the catfish became extinct after a period of stunted growth, and the minnow became locally extinct after surviving in floodplain ponds following drainage of the lake (Smith et al., 1982; Smith, in prep.). Relatives of the native sunfish and minnow are now limited, in the west, to lower elevations in the Sacramento Valley, where the frost-free period is at least 150-250 days. Introduced catfish and sunfish are also present in the Sacramento River as well as in the Snake River and other warm waters in the west (Fig. 1). The fact that the Quaternary ranges of Archoplites and Mylopharodon were forced southward hundreds of kilometers suggests that the Pliocene growing seasons on the Snake River Plain were longer than those that existed there subsequently. Recent climates on the Snake River Plain are characterized by $120-150$ frost-free days (U.S. Dep. Commerce, Climatic Atlas of the U.S., 1968). The presence of warmwater fish species whose modern relatives now live together only in the Great Valley of California implies a Sacramento-like growing season on the Miocene and Pliocene Snake River Plain.

\section{Limitation by extreme summer heat}

The coldwater fishes of the Pliocene Glenns Ferry Formation - sculpins, trout, and whitefishreach their southern limits at high elevations in mountains of the west and in colder, deeper waters of the Laurentian Great Lakes (Fig. 2, Table 2). The deepwater sculpin requires temperatures near about $4^{\circ} \mathrm{C} ; 12-14^{\circ} \mathrm{C}$ is lethal to them. The ranges of the trout, whitefish, and sculpins are characterized by cool summers. The normal average daily atmospheric temperatures of the hottest month are $22^{\circ} \mathrm{C}$, with fewer than 10 days per year above $32^{\circ} \mathrm{C}$ for the range of Myoxocephalus and usually fewer than 30 days over $32^{\circ} \mathrm{C}$ for the ranges of trout (Oncorhynchus), whitefish (Prosopium), and sculpins (Cottus). Presently the daily temperatures on the Snake River Plain during August average $22^{\circ} \mathrm{C}$, but there are more than 30 days $/ y r$ over $32^{\circ} \mathrm{C}$ (U.S. Dep. Commerce, Climatic Atlas of the U.S., 1968).

The whitefish and sculpins were absent from the system throughout most of the warmer Miocene, but became common after colonizing the lake in the early Pliocene. This colonization required two conditions, one or both of which possibly changed at that time: (1) Dispersal routes from the north and (2) cooler summers. At least two species of sculpins, one species of whitefish, and one Great Basin sucker (Chasmistes) colonized the lake at the beginning of the Pliocene. The sculpins occupied deepwater and would find a hypolimnion habitat at the temperature of the winter season. The whitefish was not a deepwater fish; its fossil remains are found most commonly in littoral sediments of the Glenns Ferry Formation. At least five additional species of sculpins came into existence in the lake during the Pliocene (Smith, 1987), but became extinct on the Snake River Plain when the lake became shallow at about $2 \mathrm{Ma}$ (Smith et al., 1982; Othberg, 1986). Assuming that hot 
TABLE 2

Coldwater fishes that inhabited the large Pliocene lake on the western Snake River Plain ("Lake Idaho"). The measure of limiting temperature is taken to be the number of annual days with temperatures over $32^{\circ} \mathrm{C}$

\begin{tabular}{|c|c|c|}
\hline & $\begin{array}{l}\text { Present } \\
\text { distribution }\end{array}$ & $\begin{array}{l}\text { Limit, days } \\
>32^{\circ} \mathrm{C}\end{array}$ \\
\hline $\begin{array}{l}\text { Myoxocephalus }(2 \mathrm{sp} .) \\
\text { (deepwater sculpin) }\end{array}$ & $\begin{array}{l}\text { Great Lakes hypolimnion to } \\
\text { Arctic Alaska and Eurasia }\end{array}$ & $<\mathrm{l} 0$ \\
\hline $\begin{array}{l}\text { Prosopium } \\
\text { (whitefish) }\end{array}$ & $\begin{array}{l}\text { High elevations and } \\
\text { northern latitudes }\end{array}$ & $<30$ \\
\hline $\begin{array}{l}\text { Oncorhynchus } \\
\text { (Pacific trout) }\end{array}$ & $\begin{array}{l}\text { Widely introduced } \\
\text { hatchery stock }\end{array}$ & $<30$ \\
\hline Kerocottus (5 sp.) & Extinct & \\
\hline
\end{tabular}

summers directly limit southern range of coldwater fishes by raising their metabolism to lethal limits, the presence of diverse coldwater fishes indicates absence of high temperatures in the lake and in connecting habitats used for immigration into the lake (Table 2).

\section{Isotopic evidence for amplitude of seasonality}

Microsamples of seasonal growth bands in an Archoplites otolith from late in the Glenns Ferry Formation yields oxygen isotopic ratios that provide a calculated temperature range from $10^{\circ} \mathrm{C}$ for winter growth to $25^{\circ} \mathrm{C}$ during summer growth (Table 3, Fig. 4). This sunfish is one of the warmwater fishes in the Glenns Ferry and Chalk Hills faunas. It inhabited the shallow littoral zone of Lake Idaho, so it provides our best estimate of atmospheric climate outside the lake. The lower limit of the temperatures measured $\left(10^{\circ} \mathrm{C}\right)$ is an underestimate of the atmospheric minimum. We are measuring the growth temperatures for Archoplites, which probably did not extend below about $10^{\circ} \mathrm{C}$ (LaRivers, 1962). Furthermore, the amplitude of atmospheric temperature variations would have been reduced by the mass of water in the large lake. For example, in western Lake Erie, the average surface temperature of the lake frequently reaches the monthly average air temperature $\left(22^{\circ} \mathrm{C}\right)$ in August (Wright, 1955). Therefore we conclude that the seasonal amplitude recorded in the sunfish otolith demonstrates a seasonal fluctuation from as low as $0-10^{\circ} \mathrm{C}$ but no higher than $25^{\circ} \mathrm{C}$. The maximum is less than that which would be recorded today.

The calculated temperatures for Pliocene Archoplites (growth at $10-24^{\circ} \mathrm{C}$ ) are congruent with the measured temperatures for growth of modern Archoplites $\left(10-29^{\circ} \mathrm{C}\right)$. The isotopic composition of carbonate in deepwater sculpins was assumed to represent accretion at about $4^{\circ} \mathrm{C}$. That assumption led to calculation of a reasonable estimate for Archoplites, providing indirect evidence that the Pliocene sculpins also lived under temperature conditions necessary for their Recent relatives.

\section{Discussion}

The faunal evidence indicates equable temperatures in Miocene and the early Pliocene lakes. Evidence for long growing seasons consists of the presence of relatives of the Sacramento sunfish, bullhead catfish, Ameiurus, and hardhead minnows, whose relatives are now restricted to the Sacramento Valley. Ameiurus has been introduced to the Sacramento Valley, where it survives and reproduces sympatric with the sunfish and minnow. Catfish and sunfish (Lepomis) have also been reintroduced to the Snake River Plain, where they maintain stunted populations. The Sacramento sunfish (Archoplites) could probably survive and reproduce in the present climate on the Snake River Plain only at low elevations near Boise in the limited area where the growing season 


\section{TABLE 3}

Oxygen isotopic composition of aragonite milled from individual growth bands of an Archoplites taylori otolith. Three separate sample sets result in the slightly different sample path widths. $\alpha$ is the isotope fractionation factor $\left(R_{\mathrm{c}} / R_{\mathrm{w}}\right.$, where $R_{\mathrm{c}}$ is the ratio ${ }^{18} \mathrm{O} /{ }^{16} \mathrm{O}$ in the aragonite and $R_{\mathrm{w}}$ is the same ratio in the water). Position ( $\mathrm{mm}$ ) is from the initial sample path during the first year of the fish's life. Temperatures were calculated using a water composition of $-15.5 \%$ SMOW and the measured carbonate isotopic compositions. Samples from $1.22 \mathrm{~mm}$ to $1.92 \mathrm{~mm}$ are diagenetically altered to calcite (see Fig. 4). SEM examination of the otolith revealed the presence of neomorphic calcite in this altered zone

\begin{tabular}{|c|c|c|c|}
\hline $\begin{array}{l}\delta^{18} \mathrm{O} \\
\mathrm{SMOW}^{1}\end{array}$ & $10^{3} \ln \alpha$ & $\begin{array}{l}\text { Calculated } \\
\text { temperature } \\
\left({ }^{\circ} \mathrm{C}\right)\end{array}$ & $\begin{array}{l}\text { Sample } \\
\text { position, } \\
\mathrm{mm}\end{array}$ \\
\hline 14.1 & 29.62 & 21.0 & 0.00 \\
\hline 13.9 & 29.46 & 21.8 & 0.07 \\
\hline 14.3 & 29.81 & 20.1 & 0.14 \\
\hline 13.5 & 29.05 & 23.7 & 0.21 \\
\hline 14.2 & 29.67 & 20.8 & 0.28 \\
\hline 15.5 & 31.05 & 14.5 & 0.42 \\
\hline 16.6 & 32.04 & 10.2 & 0.47 \\
\hline 16.7 & 32.19 & 9.5 & 0.52 \\
\hline 15.3 & 30.85 & 15.4 & 0.57 \\
\hline 14.3 & 29.86 & 19.9 & 0.62 \\
\hline 13.5 & 28.99 & 24.0 & 0.72 \\
\hline 13.2 & 28.73 & 25.2 & 0.77 \\
\hline 13.5 & 29.03 & 23.8 & 0.82 \\
\hline 14.6 & 30.11 & 18.7 & 0.87 \\
\hline 15.5 & 31.02 & 14.6 & 0.92 \\
\hline 14.3 & 29.86 & 19.9 & 0.97 \\
\hline 13.5 & 29.03 & 23.8 & 1.02 \\
\hline 14.2 & 29.71 & 20.6 & 1.12 \\
\hline 20.2 & 35.62 & -4.5 & 1.22 \\
\hline 20.3 & 35.68 & -4.7 & 1.27 \\
\hline 20.4 & 35.80 & -5.2 & 1.32 \\
\hline 20.4 & 35.79 & -5.2 & 1.37 \\
\hline 20.5 & 35.95 & -5.8 & 1.42 \\
\hline 20.4 & 36.08 & -6.3 & 1.47 \\
\hline 20.9 & 36.27 & -7.0 & 1.52 \\
\hline 20.9 & 36.31 & -7.2 & 1.57 \\
\hline 21.0 & 36.41 & -7.6 & 1.62 \\
\hline 21.2 & 36.60 & -8.3 & 1.67 \\
\hline 21.1 & 36.52 & -8.0 & 1.77 \\
\hline 21.1 & 36.53 & -8.0 & 1.82 \\
\hline 21.0 & 36.34 & -7.3 & 1.87 \\
\hline 21.1 & 36.47 & -7.8 & 1.92 \\
\hline
\end{tabular}

${ }^{1} \delta^{18} \mathrm{O}_{\mathrm{SMOW}}=\delta^{18} \mathrm{O}_{\mathrm{PDB}} * 1.03+30.9$

is longer than 150 days, and in geothermally heated waters. These species require long growing seasons (150-250 frost-free days). The Pliocene sunfish grew to much larger size than its Recent relative (Smith, 1975).
TABLE 4

Climatic parameters estimated for the Miocene, Pliocene, and Recent Snake River Plain. Paleoclimate inferred from fish distributions, especially the limiting temperature for modern closest relatives of fossil species. The seasonal range is the difference in ${ }^{\circ} \mathrm{C}$ between the mean for the coldest month and the mean for the warmest month

\begin{tabular}{|c|c|c|c|}
\hline Climate & $\begin{array}{l}\text { late } \\
\text { Miocene }\end{array}$ & Pliocene & Present-day \\
\hline Mean, coldest month & $10^{\circ} \mathrm{C}$ & $0^{\circ} \mathrm{C}$ & $-6^{\circ} \mathrm{C}$ \\
\hline Number of days $>0^{\circ} \mathrm{C}$ & 270 & 175 & 125 \\
\hline Mean, warmest month & $21^{\circ} \mathrm{C}$ & $21^{\circ} \mathrm{C}$ & $22^{\circ} \mathrm{C}$ \\
\hline Number of days $>32^{\circ} \mathrm{C}$ & 10 & 10 & 38 \\
\hline Mean annual temperature & $14^{\circ} \mathrm{C}$ & $11^{\circ} \mathrm{C}$ & $8^{\circ} \mathrm{C}$ \\
\hline Annual precipitation & $300 \mathrm{~mm}$ & $300 \mathrm{~mm}$ & $250 \mathrm{~mm}$ \\
\hline Lake evaporation & $250 \mathrm{~mm}$ & $250 \mathrm{~mm}$ & $700 \mathrm{~mm}$ \\
\hline $\begin{array}{l}\text { Seasonal range } \\
\text { in temperature }\end{array}$ & $11^{\circ} \mathrm{C}$ & $21^{\circ} \mathrm{C}$ & $28^{\circ} \mathrm{C}$ \\
\hline
\end{tabular}

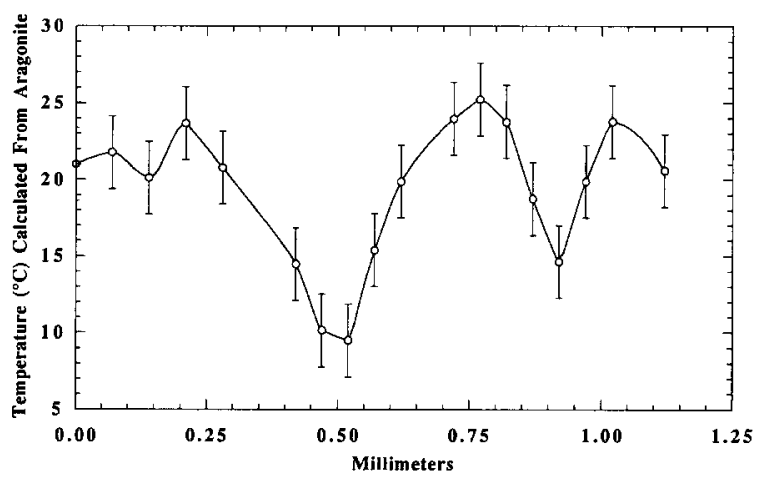

Fig. 4. Seasonal variation in surface-water temperatures calculated from oxygen isotopic analyses of aragonite from an otolith of an Archoplites taylori (sunfish) from the Pliocene Glenns Ferry Formation. The dots and line depict temperatures calculated using a water composition of $-15.5 \%$ SMOW. The vertical bars indicate temperatures calculated using $-15.0 \%$ and $-16.0 \%$ SMOW as estimates of isotopic composition of the water. Calculated summer maximum temperatures are as high as $25^{\circ} \mathrm{C}$. Diagenetic alteration of the otolith at approximately $1.2 \mathrm{~mm}$ from the initial path resulted in loss of the record of seasonal temperatures for later years of the fish's life (see Table 3).

Long growing seasons on the Miocene and Pliocene Snake River Plain are also indicated by the high growth rates of catfish (Principe, 1977) and salmonids (Smith, 1991, in prep.). Supporting data for equable climates come from the Pliocene 
Glenns Ferry mammal fauna, which includes warm-climate mammals such as Felis lacustris, hyaenid, Megalonix ground sloth, peccary, and three species of camels (Hibbard, 1972).

Evidence for cool summers is based on the early Pliocene colonization of the lake by a coldwater fish fauna of six species of sculpins, a species of whitefish, and a species of trout. This assemblage, by analogy with its modern relatives, required summers cooler than those on the Snake River Plain at present. These species indicate that the number of summer days with temperatures higher than $34^{\circ} \mathrm{C}$ were fewer than 10 then, as contrasted with more than 30 now, even though the July mean temperature was probably the same, about $21 \mathrm{C}$ (then and now), and even though the mean annual temperature was higher then, probably $11^{\circ} \mathrm{C}$ then vs. $8^{\circ} \mathrm{C}$ now. One species of sculpin (Cottus) was present in the late Pliocene Grand View Fauna (Smith et al., 1982), but the coldwater forms were absent from other late Pliocene fish faunas on the Snake River Plain (Smith, in prep.). Whitefish, trout, salmon, and three species of sculpins inhabit cold tributaries to the Snake River today. Supporting data for cooler summers on the Pliocene Snake River Plain include five species of shrews, representing a cool-climate mammalian fauna (Hibbard, 1972).

Sympatry of Arctic fishes unable to tolerate hot summers and southern fishes requiring long growing seasons supports the equability hypothesis: The Pliocene lake existed in a climate with cooler summers and milder winters than at present, until about $2 \mathrm{Ma}$.

Seasonal temperature variation was examined by measuring the isotopic composition of growth rings of a Pliocene sunfish and calculating seasonal temperatures at which it grew. Calculated peak summer growth temperature for this fish is approximately $25^{\circ} \mathrm{C}$. (Monthly summer maxima average about $24^{\circ} \mathrm{C}$ on the Snake River Plain at present.) The average temperature for the late fall, winter, and early spring did not extend below $10^{\circ} \mathrm{C}$, as recorded by the sunfish. But, the presence of deepwater sculpins indicates water temperatures as low as $0-4^{\circ} \mathrm{C}$; therefore, atmospheric extremes sufficient to cool the lake waters reached at least as low as $0-4^{\circ} \mathrm{C}$. The October to March period averages near $0^{\circ} \mathrm{C}$ on the Snake River Plain today.

For further comparison, otolith growth bands of a Lake Erie drum (a fish of similar temperature range) show temperature curves ranging between $10^{\circ} \mathrm{C}$ and $24^{\circ} \mathrm{C}$. The temperature ranges measured from littoral zone fish from each lake are $15^{\circ} \mathrm{C}$ in Lake Idaho and $14^{\circ} \mathrm{C}$ in Lake Erie, in contrast with a range of about $24^{\circ} \mathrm{C}$ for water on the Snake River Plain today.

The fauna as well as the isotopic evidence suggest that the best modern analog to the Pliocene Snake River Plain may be the northern Sacramento Valley - where the seasonal temperature range is the same as that estimated for the Pliocene Snake River Plain $\left(0-21^{\circ} \mathrm{C}\right)$. We therefore suggest that there is faunal and isotopic support for an equability hypothesis that Lake Idaho summers were cool and winters were mild, as in the upper Sacramento River Valley.

\section{Precipitation/evaporation}

The presence of a large lake required that the basin receive precipitation and runoff in excess of evaporation and discharge from the lake. A corollary to the equability hypothesis is that low evaporation would be enhanced by cool summers.

The widespread, homogeneous fauna of the lacustrine part of the Pliocene Glenns Ferry Formation indicates a lake the size of Lake Ontario; this conclusion is supported by laterally widespread, correlated transgressive beach deposits, overlying deep lacustrine deposits, and terminal regressive markers, associated with the fish fauna from an $850 \mathrm{~m}$ low stand to a $1120 \mathrm{~m}$ high stand elevation, from near Hagerman, Idaho, to Willow Creek, Oregon.

The widespread, homogeneous, but different, lacustrine fauna of the Miocene Chalk Hills Formation also indicates a large lake. This fish fauna contained no sculpins and no whitefish, but more abundant sunfish and catfish, indicating warmer winters and longer growing seasons than in the Pliocene or Recent. Chalk Hills lake deposits are $100 \mathrm{~m}$ lower in elevation than the Glenns Ferry high stand. The Lake was smaller, but is recorded 
from near Bruneau, Idaho, to Vale, Oregon (Kimmel, 1982).

The presence of a large lake would have caused a more equable local climate than would exist without the lake. Furthermore, an equable climate would have contributed to the existence of the lakes, because hot summers and excessive evaporation desiccate lakes as in the Holocene history of the Great Basin. The causal cycle involving decreased seasonality and the maintenance of a large lake is a positive feedback system in which the large area of surface water lowers regional temperature, which decreases evaporation. These facts require an attempt to differentiate between lake effects on atmospheric temperatures and atmospheric effects on the lake temperature. It is possible that the presence of the lake would be sufficient to yield the seasonal temperatures indicated by the faunal and isotopic evidence. Warmwater sunfish and catfish and coldwater salmonids and sculpins live (at different depths) in Lakes Michigan, Huron, and Ontario, for example (Bailey and Smith, 1981). Yet the terrestrial climate of the Great Lakes region is not equable today. (Catfish and sunfish are much less abundant in the upper Great Lakes than in Lake Idaho.) The coldand warm-water inhabitants simply required sequential cold glacial and warm post-glacial periods to enable their separate colonization of the Great Lakes. There was no comparable glacial climate to permit early Pliocene colonization of the Snake River Plain. Immigration of sculpins and whitefish from the northern North America to southwest Idaho required routes of permanently cool water provided either by high mountains or absence of hot summers.

We assume that an excess of precipitation over evaporation in the drainage basin is necessary to maintain large, permanent lakes for long periods. The position of the lake in southwest Idaho, $600 \mathrm{~km}$ from the Pacific coast, implies limited precipation, perhaps like northern Idaho today, unless the Cascade rainshadow effect was much smaller. Miocene algal carbonate (Straccia et al., 1990) and Pliocene oolite (Swirydczuk et al., 1980) suggested evaporitic conditions (Malde and Powers, 1962), but extremely low values for $\delta^{18} \mathrm{O}$ $(-12$ to $-17 \%$, mean $=-16 \%$; Drummond et al., 1993 and original data) contradict this inference. Lakes with similarly depleted ${ }^{18} \mathrm{O}$ today are cold and get depleted runoff at high latitudes or elevations. (They do not precipitate voluminous carbonates).

Condensation of rain and especially snow depletes ${ }^{18} \mathrm{O}$ in the atmosphere, the fractionation being more extreme at the lower temperatures associated with high elevations and latitudes (Faure 1986). Tributaries from high elevations or northern, far inland sources are consequently depleted in ${ }^{18} \mathrm{O}$. Evaporation would enrich ${ }^{18} \mathrm{O}$ in the lake, making extreme negative values such as those in Table 3 unlikely (Drummond et al., 1993). These observations support the hypothesis that the lake was not extremely evaporative at times represented by the fossils analyzed, providing a third line of evidence that the summers were cool. The lakes were probably built up and maintained in part by precipitation at high elevations in the surrounding mountain sources: The Upper Snake River in the Yellowstone area, Idaho batholith, Jarbidge Mountains, and Owyhee Mountains supplied the lakes' tributaries. Weather came from westnorthwest as today, as suggested by the increasing trend of depleted ${ }^{18} \mathrm{O}$ from the Snake River Plain to the Camp Davis Formation (Miocene, Wyoming), which had $\delta^{18} \mathrm{O}$ values as low as $-35 \%$ (Drummond et al., 1993).

Depleted $\delta^{18} \mathrm{O}$ values of the Miocene carbonates from Idaho and Wyoming present an unexpected topographic conflict. Isotopic values as low as $\delta^{18} \mathrm{O}=-16 \%$ represent depletion of ${ }^{18} \mathrm{O}$ like that of far northern lakes in Canada and high altitude lakes in Europe. Since the Pliocene latitude of the Snake River Plain was the same as today's, high elevation source waters have been proposed to explain the carbonate depleted in ${ }^{18} \mathrm{O}$ (Drummond et al., 1993). This places us in conflict with previous reconstructions, for example Dwight Taylor's interpretations of mollusks and Jane Gray's interpretation of the pollen record, that entail low elevations with no high mountains in the Miocene and Pliocene of the Pacific Northwest (Gray and Taylor, 1992). High elevation source waters in the region are required to explain the depleted ${ }^{18} \mathrm{O}$ in Miocene and Pliocene carbonates in western Wyoming and southern Idaho, and would also 
help explain the colonization of the Snake River Plain by extreme coldwater forms in the early Pliocene.

In summary, the climate of the Snake River Plain was more equable in the Miocene and Pliocene than at present. Miocene climates were much warmer in the winter and moderately cooler in the summer. Pliocene summers experienced fewer hot summer days, possibly cooled by cold lakes and streams, but winters were warmer than those on the Snake River Plain today. It is possible that the seasonal equability of the Miocene and Pliocene derived from greater diurnal equability, which was, in turn, caused by the presence of a large, deep lake.

\section{Acknowledgements}

K.C Lohmann provided guidance throughout the study and helpful comments on the manuscript. Bruce Wilkinson, Karl Drummond, and Dan Fisher offered useful advice.

\section{References}

Bailey, R.M. and Smith, G.R., 1981. Origin and geography of the fish fauna of the Laurentian Great Lakes Basin. Can. J. Fish. Aquat. Sci., 38 (12): 1539-1561.

Blaxter, J.H.S. (Editor), 1974. The Early Life History of Fish. Springer, New York.

Brothers, E.B., Mathews, C.F. and Lasker, R., 1976. Daily growth increments in otoliths from larval and adult fishes. Mar. Fish. Serv. Fish. Bull., 74: 1-8.

Campana, S.E. 1983. Calcium deposition and otolith check formation during periods of stress in coho salmon, Oncorhynchus kisutch. Comp. Biochem. Physiol., 75A: 215-220.

Degens, E.T., Deuser, W.G. and Haedrich, R.L., 1969. Molecular structure and composition of fish otoliths. Mar. Biol. 2: 105-113

Devereux. I., 1967. Temperature measurements from oxygen isotope ratios of fish otoliths. Science, 155: 1684-1685.

Drummond, C.N., Wilkinson, B.H., Lohmann, K.C. and Smith. G.R., 1993. Effect of regional topography and hydrology on the lacustine isotopic record of Miocene paleoclimate in the Rocky Mountains. Palaeogeogr., Palaeoclimatol., Palaeoecol., 101: 67-79.

Faure, G., 1986. Principles of Isotope Geology. Wiley, New York.

Gauldie, R.W., 1993. Continuous and discontinuous growth in the otolith of Macruronus novaezelandiae (Merlucciidae: Teleostei). M. Morphol., 216: 271-294.

Graham, R.W. and Meade, J.I., 1987. Environmental fluctuations and evolution of mammalian faunas during the last deglaciation in North America. In: W.F. Ruddiman and J.E. Wright Jr. (Editors), North America and Adjacent Oceans During the Last Deglaciation (Geol. North America, K-3). Geol. Soc. Am., Boulder, CO.

Gray, J. and Taylor, D.W., 1992. Late Tertiary environmental changes: Pollen and mollusc evidence from the Pacific Northwest. Geol. Soc. Am. (Rocky Mtn. Div.) Program and Abstracts 1992.

Gustafson, E.P., 1978. The vertebrate faunas of the Pliocene Ringold Formation, south-central Washington. Univ. Oregon Mus. Nat. Hist. Bull., 23: 1-62.

Hibbard, C.W., 1960. An interpretation of Pliocene and Pleistocene climates in North America. Ann. Rep. Mich. Acad. Sci. Arts Lett., 62: 5-30.

Hibbard, C.W., 1972. Class Mammalia.In: M.F. Skinner and C.W. Hibbard (Editors), Early Pleistocene Pre-glacial and Glacial Rocks and Faunas of North-central Nebraska. Am. Mus. Nat. Hist. Bull., 148: 77-130

Hutchinson, G.E., 1957. A Treatise on Limnology. I. Geography, Physics and Chemistry. Wiley, New York.

Kimmel, P.G., 1982. Miocene-Pliocene lacustrine sediments of the western Snake River Plain: their stratigraphy, age, and tectonic setting. In: B. Bonnichsen and R.M. Breckenridge (Editors), Cenozoic Geology of Idaho. Idaho Bur. Mines Geol. Bull., 26: 559-578 pp.

King, C., 1878. Systematic Geology: U.S. Geological Exploration of the 40th Parallel. Washington, DC, 1.

LaRivers, I., 1962. Fish and Fisheries of Nevada. Nev. State Fish Game Comm., Reno.

McCarraher, D.B. and Gregory, R.W., 1970. Adaptability and status of introductions of Sacramento perch, Archoplites interruptus, in North America. Trans. Am. Fish. Soc., 99: $700-707$.

Mathews, S.B., 1965. Reproductive behavior of the Sacramento perch, Archoplites interruptus. Copeia. 1965: 224-226.

Murphy, G.I., 1948. A contribution to the life history of the Sacramento perch (Archoplites interruptus) in Clear Lake, Lake County, California. Calif. Fish Game. 34: 93-100.

Othberg, K., 1986. Late Cenozoic geology and the tenmile gravel near Lucky Peak Dam, Idaho. In: Proc. 22th Symp. Eng. Geol. Soils Eng. Idaho Geol. Surv., pp. 533-545.

Panella, G., 1971. Fish otoliths: Daily growth layers and periodical patterns. Science, 173: 1124-1126.

Principe, P.A., 1977. A late Pliocene (Ringold Formation) fish fauna from south-central Washington and its distributional significance to the Columbia-Snake drainage systems. Thesis. Univ. Mass.

Patterson, W.P., Smith. G.R. and Lohmann, K.C., 1993. Continental paleothermometry and seasonality using the isotopic composition of aragonitic otoliths of freshwater fishes. In: P. Swart, K.C. Lohmann, J. McKenzie and S. Savin (Editors), Continental Climate Change from Isotopic Indicators (Am. Geophys. Union Monogr.) Am. Geophys. Union, Washington, pp. 191-202.

Radtke, R.L., 1984. Cod fish otoliths: Information storage structures. In: E. Dahl, D.S. Danielssen, E. Moksness, and P. Solemdal (Editors), The Propagation of Cod Gadus morrhua. Floedevigen Rapp. I. Arenda, Norway, pp. 273-298.

Smith, G.R., 1975. Fishes of the Pliocene Glenns Ferry 
Formation, Southwest Idaho. Univ. Mich. Mus. Paleontol. Pap. Paleontol., 14: 1-68.

Smith, G.R., 1978. Biogeography of intermountain fishes. In: K.T. Harper and J.L. Reveal (Editors), Intermountain Biogeography: A Symposium. Great Basin Nat. Mem., 2; $17-42$.

Smith, G.R., 1981. Late Cenozoic freshwater fishes of North America. Ann. Rev. Ecol. Syst., 12: 163-193.

Smith, G.R., Swirydczuk, K., Kimmel, P.G. and Wilkinson, B.H., 1982. Fish biostratigraphy of late Miocene to Pleistocene sediments of the western Snake River Plain, Idaho. In: B. Bonnichsen and R.M. Breckenridge (Editors), Cenozoic Geology of Idaho. Idaho Bur. Mines Geol. Bull., 26: 519-542.

Smith, G.R., 1987. Fish speciation in a western North American
Pliocene rift lake. Palaios, 2: 436-445.

Straccia, F.J., Wilkinson, B.H. and Smith, G.R., 1990. Miocene lacustrine algal reefs--southwestern Snake River Plain Idaho. Sediment. Geol., 67: 7-23.

Swirydczuk, K., Wilkinson, B.H. and Smith, G.R., 1980. The Pliocene Glenns Ferry Oolite II: Sedimentology and oolitic lacustrine terrace deposits. J. Sediment. Petrol., 50(4): 1237-1248.

U. S. Dep. Commerce, 1968. Climatic Atlas of the United States. Environ. Sci. Serv. Adm., Washington, DC.

Urey, H.C., 1947. The thermodynamic properties of isotopic substances. J. Chem. Soc., 1947: 562-581.

Wright, S., 1955. Limnological survey of western Lake Erie. Spec. Sci. Rep. U.S. Fish Wildl. Serv. Fish., Washington, DC, 139. 